\title{
New Hungarian science union to face post-Kadar era
}

\section{London}

Hungary's new Democratic Union of Scientific Workers was formally established on 14 May. Following a postal survey of Hungary's 2,000 research establishments (see Nature 352, 385; 1988) it was decided to set up a single union for all scientists and academic researchers. This cuts across Hungary's existing union structure, which makes union membership dependent on workplace, and so spreads the country's 77,000 scientists and academic researchers between 16 unions. The relationship of the new body with the existing National Trade Union Council (SZOT) is at present undefined.

During the past year, hundreds of thousands of Hungarians have left the existing union movement. The scientists' discontent, however, goes back a number of years, as, according to Csabo Oeri, one of the spokespersons for the new union, the scientists have felt their personal and professional situation to have been consistently "devalued". Unlike the SZOT unions, the new organization, being independent of the workplace, will be able to take care of scientists who lose their jobs. More than 1,000 scientists and academic researchers have already joined.

The scientists' initiative is likely to inspire other professions to set up independent unions. Gyoergy Kerekes, another spokesman of the new union and an active party member, predicts that in two years there will be several dozen profession-based unions. Not surprisingly, there is some reticence, even in the academic establishment, towards the new body. (The founding meeting could not be held on university or academy premises, but was held in a metal-workers club.)

The founders of the Democratic Union of Scientific Workers stress, however, that they do not want to challenge the state nor to become a political force in the style of Poland's 'Solidarity'. What they want, they say, is to stand up for the rights of the country's scientists and scholars, "with a minimum of bureaucracy and a maximum of democracy".

Vera Rich

Although Hungary's new party leader, Karoly Grosz, has made clear his commitment to the "democratization" of Hungarian life, his attitude to the concept of "alternative" unions is somewhat negative - to judge from an interview he gave the government newspaper Magyar Hirlap in April. During his visit to London, three weeks ago, Mr Grosz was asked to enlarge on this apparent dichotomy, he said that he respected other people's opinions on multi-party systems, and independent trade unions and youth organizations and that he had the right to expect other people to respect his views too.

\section{Labour outlines policy for more industry-led research}

\section{London}

A Future Labour government in Britain would base its industrial strategy on greater public and private investment in science, research and development, the party's trade and industry spokesman said last week. Delivering the last in a series of speeches on the party's recipe for industrial and economic growth, Bryan Gould insisted that Britain needs an "industrial and technological revolution" to remedy "our dismal record on science".

In the first instance, investment in basic science must increase, and greater account must be taken of the rapidly rising costs of vital equipment. The demand by the pressure group Save British Science for an immediate injection of $£ 100$ million followed by a 10 per cent increase in civil research spending over the next five years "is a modest starting point" Gould says.

As part of its "medium-term industrial strategy" a Labour government would launch several initiatives to encourage greater investment by industry in research and development. Companies would be obliged to disclose their research and development expenditure. "We should seek to change the accounting practice which regards $R \& D$ spending as a drain on liquidity rather than an investment in an asset", Gould says.

Such moves would not, however, make many inroads into the $£ 3,000$ million increase in industry-backed civil research and development deemed necessary by Gould, who points out that even the present investment is dominated by just three industries - electronics, aerospace and chemicals - which spend about ten times as much on research and development per employee as the rest of manufacturing.

A Labour government would therefore want to assist specific companies to increase their research spending, for example by a grant related to the increase in research and development undertaken, "although to stop all funds going to the existing high-tech firms there might need to be a ceiling put on the overall sum or the amount per employee", Gould says.

Simon Hadlington

\section{Arizona backs insects}

A \$3.2-million Center for Insect Science at the University of Arizona is one of three new projects that will receive funds from the National Science Foundation (NSF) under its biological research centres programme.

The University of Arizona centre embodies the traditional goals of entomology departments and agricultural experimental stations as well as more speculative efforts to discover new uses for insects and to use them as models for understanding mammalian systems.

"We think it's a vastly neglected group of animals", says John H. Law, the centre's acting director. Nicholas J. Strausfeld, a professor of neurobiology and a member of the centre, says that insects are potentially a guide to the development and functional organization of complex nervous systems. The NSF funds will be used over the next four years to train 63 undergraduate and graduate students and postdoctoral researchers in insect biological sciences and to support short-term trainees.

The new centre expects to get $\$ 1.7$ million from the $\$ 6$ million-dollar NSF programme. The University of California at Berkeley and Johns Hopkins University are the two others, out of the sixteen finalists, to get grants from the research centre's programme.

E.P.

\section{Nicotine addiction}

Nicotine is the drug in tobacco that causes addiction. That is the conclusion of the twentieth US Public Health Service report on the health consequences of smoking released last week. The 618-page report chronicles the pharmacological and behavioural basis for nicotine addiction, showing that it acts in a way similar to that of cocaine and heroin.

Surgeon General C. Everett Koop argues that prevention of tobacco use should be included along with prevention of illicit drugs use in school health education programmes. He further suggests that policy makers should question whether tobacco sales outlets should be licensed just as are alcohol sales outlets.

J.P.

\section{Demolition halted}

BulLDOZER operations on the site of a Byzantine cemetery in the southern Crimea (see Nature 333, 198; 1988) have now been halted, according to a message just received from the Leningrad Institute of Archaeology of the Soviet Academy of Sciences. The site was being cleared - in defiance of Soviet regulations on archaeological finds - so that a rest home could be built for the Soviet Academy of Sciences. This paradoxical - and illegal - situation seems to have resulted from the attempts of a local functionary of the academy to build himself a personal power base. He has now been formally reprimanded. 